\title{
Waar begin en waar eindig die amp
}

\section{A D PONT}

Gedurende die afglope 25 jaar is daar in ons Kerk verskillende kere uitvoerig oor die amp en wat daarmee saamhang gepraat en op verskillende kerklike vergaderings is ook belangrike besluite in hierdie verband geneem. Dit het 'n paar keer gebeur dat professor Piet Dreyer en die skrywer hiervan oor hierdie sake verskil het. Waar ek nou in hierdie feesbundel tot sy eer óók'n artikel mag skrywe, het ek gedink om hierdie saak van die amp weer aan te roer. Nié om daarmee my standpunte nog weer 'n keer te beklemtoon nie, maar om 'n saak weer te berde te bring waaroor die laaste woord nog nie gesê is nie. Op hierdie wyse wil ek ook graag ' $n$ huldeblyk bring aan 'n ouer universitêre en kerklike kollega wat op 'n besondere wyse kateder en kansel met mekaar in sy persoon verbind het en op altwee hierdie terreine met vrug en onderskeiding geleef en gewerk het.

Wanneer nou gehandel word oor die vraag wáár die amp begin en eindig, dan is dit, in die eerste plek, duidelik dat die vraag sowel 'n formele as ' $n$ materiële antwoord vra. Voordat egter daarby gekom kan word, sal daar tog net weer 'n oomblik stilgestaan moet word by die ander vraag oor wat presies onder amp verstaan moet word en dan veral ten opsigte van die amp van dienaar van die Woord. Juis omdat die ampsbegrip nie so 'n vanselfsprekende saak is nie, kan 'n oomblik daarby stilgestaan word.

\section{Die Amp van dienaar van die Woord}

Die amp in die kerk is nié ' $n$ menslike instelling nie. Ons Heer Jesus Christus self wat van die begin af mense gebruik het om sy gemeente bymekaar te maak, te versorg en te regeer, het die amp ingestel.

Die karakter van die amp word in die Nuwe Testament aangedui as 'n dienswerk, 'n diakonia, en so noem Paulus homself en sy mededienaars dienaars van die nuwe testament of verbond. In hierdie dienende werk het Christus die apostels en die ander voorgegaan (Mark 10:45). Hierdie dienswerk het die Vader aan Christus opgedra (Joh 4:34), en Hy is die dienaar van God in en ten behoewe van die gemeente, Hy verrig sy dienswerk tot verlossing en tot saligheid van die mens. So gesien is Christus self die koning, profeet en priester van sy gemeente, $\mathrm{Hy}$ is die apostel, die herder, leraar en die wetgewer van sy gemeente.

Nou roep Christus ook mense deur wie Hy hierdie dienswerk in die gemeente kon doen en laat doen. Dáárom is die dienswerk, die amp in die gemeente, altyd iets wat in gehoorsaamheid aan Christus en na die reël van sy Woord gedoen moet word. 
Ná sy opstanding en hemelvaart daal die Heilige Gees op die apostels neer sodat hulle bekwaam gemaak word, in staat gestel word om die dienswerk te doen, en sodat hulle met gesag kan optree in die wete dat hulle deur Christus self tot die amp geroep is. Die apostels beskou hulle amp dan ook as 'n dienswerk ten bate van die gemeente, 'n opdrag wat hullle van God self ontvang het (I Kor 4:1; 11:23). So noem Paulus homself tegelyktertyd ' $n$ kneg van God (Rom 1:1) en 'n diakonos van die gemeente, want sy arbeid is ten behoewe van die gemeente. Die apostel is egter nié ' $\mathrm{k}$ kneg van die gemeente asof dié hom kan beveel nie (I Kor 7:23).

Ons amp wat myns insiens ' $n$ voortsetting is van die amp van die apostel, wat die "oer-amp" in die kerk beklee het, beteken dus dat die ampsdraer 'n dienaar van Christus ten behoewe van die gemeente is (II Kor 4:5). Christus self het die amp aan sy gemeente gegee (Ef 4:11 v v) en as Hoof van die kerk gebruik hy die amp as 'n middel in sy hand om so die gemeente te vergader, in stand te hou, uit te brei ensovoorts.

Die ampsdraer is dus in die eerste plek ' $n$ dienaar van Christus en in afhanklikheid van Christus moet hulle hulle werk doen. Daarom stel Heinrich Bullinger in die Tweede Switserse Geloofsbelydenis (17.8 en 18.4) in 1566:

"Want ons hou daaraan vas en ons leer dat Christus ons Heer is en altyd die algemene herder sal bly, die hoogste biskop voor God die Vader, en dat in die kerk Christus alle funksies van herder en biskop uitvoer, tot aan die einde van die tyd, en dat Hy daarom geen behoefte het aan 'n plaasvervanger, wat die plek van die afwesige inneem nie, maar Christus is teenwoordig in die kerk en $\mathrm{Hy}$ is die lewende en besielende Hoof van die kerk."

En dan ook:

"Want Christus plaas nie die regering van die kerk op die skouers van ander nie, maar Hy behou en gebruik tot nou toe nog sy mag, terwyl Hy self alle dinge regeer."

Die koningskap van Christus oor sy kerk is die voorwaarde om die amp te verstaan as ' $n$ dienswerk in die kerk. Daarom moét, ten opsigte van die amp, die klem altyd val op die dienende karakter van die amp.

Die amp in die kerk het nie ' $n$ heersende of 'n gesagskarakter nie maar alléén 'n dienende karakter. Daar is net een Heer in die kerk en gemeente, en dit is Christus en nié die amp of die ampsdraer nie. Die ampsdraers is slegs dienaars van Christus ter wille van die gemeente (I Kor 3:22; II Kor 4:5; Ef 4:12). 
Die feit dat Christus die amp instel en gebruik, beteken nog nié dat die ampsdraers ' $n$ afsonderlike stand of groep, 'n clerus in die kerk is nie. Hoewel die goddelike instelling van die amp benadruk moet word, is daar geen beginselverskil tussen die ampsdraer en die gewone gelowige nie. Die enigste verskil hier is dat die ampsdraer tot ' $n$ besondere dienswerk geroep word, maar daardie roeping verhef die ampsdraer nie bokant die gewone lidmaat nie. Daarom is die amp in die Reformatoriese kerk nooit 'n officium, 'n gesaghebbende heersersposisie nie maar 'n diens, ' $n$ ministerium wat in gehoorsaamheid aan Christus beoefen moet word.

Die ander aspekte van die amp naamlik die noodsaaklikheid daarvan, die gesag van die amp, die prinsipiële gelykwaardigheid van die verskillende ampte en derglike meer kan vir die doeleindes van hierdie argument nagelaat word.

\section{Die Begin van die Amp}

Die ampsdraer self word uit die gemeente geroep. Die primêre voorwaarde vir die amp is dat die geroepe ampsdraer 'n geroepe gelowige sal wees. Naas die algemene roeping tot die geloof ontvang die ampsdraer 'n verder roeping, die roeping tot die amp.

In die roeping tot die amp onderskei Joh Calvyn' $n$ inwendige en 'n uitwendige roeping. Die inwendige roeping word dan soos volg aangedui:

die verlening van die gawes wat vir die amp vereis word;

die standvastige begeerte of strewe na die amp; en

die opening van die weë wat tot die amp lei.

Hierdie inwendige roeping in die roeping tot die amp is daardie roeping wat 'n "gewone" gelowige daartoe bring om die teologiese studie aan te pak en dit met volhardende ywer te voltooi. In daardie, byna prosaïese gebeure van studie mag die gelowige ook ' $n$ roeping ervaar.

Daar moet op gelet word dat in die tyd van die Kerkhervorming daar baie sterk gevoel is dat niemand hom moet probeer indring in die amp van dienaar van die Woord nie. Die Switserse hervormer Zwingli stel dit so:

"'n Ernstige Christengelowige het nog nooit een van hierdie ampte op homself geneem nie tensy hy, in die eerste plek, deur God gestuur is nie of tensy hy deur die kerk of die apostels daartoe uitgekies is nie, en die laaste is niks minder as 'n roeping of 'n opdrag nie."

Dié saak is van so ' $n$ groot belang geag omdat geoordeel is dat die prediking van die Woord, die bediening van die sakramente en die 
hantering van die dissipline sulke gewigtige aangeleenthede is dat die gelowige dit alleen kan doen as hy daarvoor 'n opdrag van God self of van die kerk gekry het.

Nadat die teologiese student sy teologiese studie afgehandel het, kan hy homself by die bevoegde kerklike vergadering aanmeld as kandidaat vir die amp van dienaar van die Woord. Ook die toelating tot die amp was en is ' $n$ belangrike aangeleentheid. Die Artikels van Wezel 1568 bepaal onder andere:

"En voor eerste is geheel noodig dat niemand tot de kerkendienst en enige andere kerkelijke bediening in de gemeente wordt toegelaten zonder wettelijke roeping, verkiezing, toestemming, behoorlijk examen of onderzoek en wettelijke orde."

Met ander woorde nadat die inwendige roeping die gelowige tot die voltooiing van die teologiese studie gelei het, moet daarop die uitwendige roeping tot die amp volg, dit wil sê 'n beroep wat deur 'n gemeente uitgebring word.

Tussen die voltooiing van die telogiese studie en die moontlikheid om 'n beroep van 'n gemeente te ontvang, lê die proponentseksamen. Dit is ' $n$ kerklike ondersoek nie net na die akademiese kwalifikasies van die kandidaat-tot-die-amp nie maar ook 'n ondersoek na sy geestelike en sedelike gawes om vas te stel of hy geskik is vir die amp. Ons Kerkwet stel die saak so dat hierdie ondersoek gedoen word om te bepaal:

of elke kandidaat voldoende kennis van die Heilige Skrif met die oog op die ampspraktyk besit, en

in hoe verre die akademiese opleiding deur die Teologiese Opleiding deel geword het van die hart en lewe van die betrokke kandidaat.

Die akademiese opleiding is nie die enigste weg waarlangs iemand tot die amp kan kom nie. In die Kerkorde van Dordrecht 1619 art 8 word die moontlikheid oopgelaat dat iemand met "singuliere gaven" ook tot die amp toegelaat kan word. Die besondere gawes word dan genoem, nl "godsaligheid (=vroomheid), oormoedigheid, sedigheid, 'n goeie verstand en diskressie en welsprekendheid." Die Skotse Second Book of Discipline stel dat die proponentseksamen veral daarop gerig is om die "soundness of religion and godliness of life" van die kandidaat vas te stel.

Ons beklemtoning van die teologiese studie vind sy herkoms in die Calvinistiese hervorming, waar die klem sterk gelê is op die vermoë van die kandidaat om in sy prediking die Skrifte uit te lê. Die Akademie in Genève wat deur Calvyn vir die opleiding van predikante opgerig is, het 'n stewige studieprogram aan die teologiese 
student voorgelê. Nie alleen is ' $n$ deeglike studie van die klassieke tale gedoen nie, maar daar is ook aandag gegee aan die etiek, die filosofie, die uitleg van die Skrif en die leer van die kerk.

$\mathrm{Na}$ dié opleiding en die proponentseksamen, waarby 'n proefpreek as vanselfsprekend beskou word, word 'n kandidaat beroepbaar gestel. Hy word dan 'n proponent, dit wil sê 'n kandidaat wat vir die amp van dienaar van die Woord beroepbaar is. Dit is so ver as wat die inwendige roeping 'n gelowige kan voer op die pad na die amp van dienaar van die Woord.

'n Vaste onderdeel van die toelating tot die amp is dat ná die aflê van die proponentseksamen die proponent die proponentsondertekeningsformule sal onderskryf. Dié ondertekning is ' $n$ belofte dat die kandidaat die regte Bybelse leer soos dit in die belydenisskrifte voorkom, nie net aanvaar nie maar ook sal uitdra. Daarby kom dan ook die belofte dat die kandidaat die orde van die kerk sal gehoorsaam en handhaaf.

Reeds vanaf die begin van die Hervorming is dit duidelik dat die prediking na die norm en reël van die suiwere, Bybelse leer as besonder belangrik beskou is. In Nederland het die Wezelse Artikels dit as voldoende beskou as die kandidaat sy aanvaarding van die belydenis en kategismus as norm en reël van die prediking mondeling aanvaar. In 1571 word al ' $n$ ondertekening van die belydenisskrifte vereis en in 1608 word die eerste maal 'n formule ontwerp wat onderteken moet word en daarvolgens verklaar die kandidaat hoe hy die belydenisskrifte onderteken.

Wanneer in Nederland daar al meer predikante na vore kom wat tog afwykende menings op die kansel stel, word hierdie proponentsformule al hoe meer spesifiek en duidelik omlyn. Die Dordtse formule stel drie sake pertinent:

dat die kandidaat al die stukke en artikels van die belydenisskrifte glo en aanvaar dat dit in alles met Gods Woord ooreenkom;

dat hy beloof om die leer "getrouwelijk" te leer en voor te staan en alles wat in stryd daarmee is, sal verwerp en bestry;

dat hy beloof om, indien hy enige bedenkings oor dié saak het, die sake eers by die vergaderings van die ampte ter sprake te bring en by hulle uitspraak sal berus.

Ons formule wat min of meer dieselfde inhoud het, eis ook nog stiptelike gehoorsaamheid aan die Wet en Bepalings, en die belofte van onderwerping aan die oordeel van die bevoegde vergaderings van die ampte. Hierdeur aanvaar die kandidaat dat die belydenisskrifte wat in ooreenstemming met Gods Woord is, die norm en reël vir die prediking is en dat daar in die kerk geen afwyking van hierdie regte en suiwere leer sal wees nie. 
Nadat die kandidaat dus so beroepbaar gestel is, moet hy nog tot die amp self toegelaat word. Hiervoor is die uitwendige roeping nodig, naamlik die beroep na 'n gemeente of 'n werkkring. Eers dan kan in die amp ingetree word. ' $n$ Vaste beginsel is dat die amp of dienswerk alleen in 'n bepaalde werkkring beoefen kan word. Die moontlikheid om dienaar van die Woord sonder ' $n$ vaste werkkring te wees, word in die Reformatoriese kerkreg altyd afgewys. Dit gebeur juis omdat die amp nié ' $n$ status of ' $n$ gesagsposisie is nie maar 'n dienswerk, en 'n dienswerk kan nie in 'n lugleegte gedoen word nie maar alleen in ' $n$ vaste werkkring. Dit is dus duidelik dat ons hier met 'n funksionele ampsopvatting te maak het. Daarom is daar ook 'n reël dat 'n proponent sonder 'n beroep se "status" of posisie van tyd tot tyd hersien moet word. Kry 'n proponent geen beroep nie, sal na verloop van tyd sy proponentstatus verval, want dan beteken dit dat die inwendige roeping tot die amp nié deur 'n uitwendige roeping as ' $t$ ware voltooi is nie.

Die uitwendige roeping, die beroep dus, kan alleen deur ' $n$ kerkraad uitgebring word nadat die kerkraad daartoe magtiging van die gemeente ontvang het. By die uitbring van 'n beroep is die stem van die gemeente wel op die agtergrond maar dit is tog daar. Dit hang saam met die feit dat in die Nuwe Testament die gemeente ' $n$ belangrike rol in die verkiesing tot die amp gespeel het soos dit nou nog ook by die verkiesing van ouderlinge en diakens gehandhaaf word in ons kerklike lewe.

Nadat die beroep uitgebring en aanvaar is, word die proponent, die kandidaat tot die amp, in die amp bevestig. Hierdie bevestiging in die dienswerk is 'n plegtige gebeurtenis, want hier word 'n gelowige afgesonder vir ' $n$ belangrike dienswerk in die gemeente. Die bevestiging vind altyd in die openbaar plaas tydens ' $n$ godsdiensoefening en in die formulier wat gebruik word, word bepaalde vrae aan die kandidaat gestel.

In die Reformatoriese tyd is die belangrikheid en plegtigheid van die gebeure onderstreep deur die eis dat die gemeente en almal wat by die bevestiging betrokke is, hulle sal onthou van voedsel. Dit is gedoen na aanleiding van Handelinge 14:23 "En hulle (= Paulus en Barnabas) het in elke gemeente vir hulle ouderlinge gekies, en hulle, na gebed en vas, opgedra aan die Here in wie hulle geglo het." Selfs Calvyn verwys na die gebruik om te vas en ook die Sinode van Dordrecht 1618-19 verwys hier na die noodsaaklikheid van "vasten en bidden". Die Calvinistiese Westminster Assembly van 1636 stel in hierdie verband:

"Upon the day appointed for ordination, ..., a solemn fast shall be kept by the congregation, that they may the more earnestly join in prayer for a blessing upon the ordinance of Christ, and the labours of His servant for their good." 
Nadat die kandidaat in die godsdiensoefening die formulier aangehoor het, word die vrae aan hom gestel:

of hy in sy hart voel dat hy wettig deur die gemeente en daarom deur God self tot die heilige diens geroep is;

of hy die Ou Testament en die Nuwe Testament hou vir die enige Woord van God; en

of hy sy dienswerk getrou sal bedien en 'n vrome lewe sal lei en hom aan die kerklike dissipline en tug sal onderwerp indien nodig.

Nadat die kandidaat bevestigend geantwoord het, word hom die hande opgelê óf die regterhand van gemeenskap gereik wat beide prakties presies dieselfde beteken naamlik' $n$ gebaar van afsondering tot die bepaalde dienswerk. Hier is geen sprake van 'n oordrag van die gawes van die amp soos by Rome nie. Polyander stel dit so:

"Dus moeten niet uit de opeenvolging van de persoonlijke successie, maar van de ware leer, de goede Herders van de huurlingen en rowers ... onderkend worden."

Hoewel die handoplegging soms misverstande gewek het, is dié gebruik deurentyds gehandhaaf hoewel dit steeds afgegrens word teen 'n Roomse opvatting al sou dit 'n sakramentele gebaar wees.

So lei die pad van die gelowige deur die teologiese studie tot die afsondering in die dienswerk van dienaar van die Woord. Die Reformatoriese vadere het geoordeel dat die predikant met sy bevestiging lewenslank afgesonder is vir dié dienswerk in daardie betrokke gemeente.

\section{Materiële Aspekte}

As gevra word na die materiële begin en einde van die amp van dienaar van die Woord, dan kan daar net één antwoord wees: die prediking, die verkondiging, die uitleg en toepassing van die Woord van God. Dit is en bly die konstituerende element van die dienswerk, dit is en bly die hooftaak van die predikant. Die Tweede Switserse Geloofsbelydenis van Bullinger stel dit in art 18 so:

"Daarom, wanneer vandag hierdie Woord van God in die kerk verkondig word deur middel van predikante wat wettig geroep is, glo ons dat die ware Woord van God verkondig is, en dit moet deur die gelowiges aanvaar word, nog moet enige ander Woord van God versin word of uit die hemel verwag word."

Saam met die prediking gaan die bediening van die sakramente, die verbum visibilis van Augustinus en die regering van die gemeente 
saam met die ouderlinge. Die diens van die gebede word normaalweg as ' $n$ vaste onderdeel van die prediking gesien.

Naas hierdie primêre taak het die predikant ook die opdrag om die kategese waar te neem, huwelike te bevestig, begrafnisse te hou, reëlmatig die lidmate te besoek, siekes en gevangenes te vertroos en saam met die ander ampte die gemeente en kerk te regeer.

Om sy amp te kan volvoer, woon die predikant in die gemeente, en om te kan lewe, ontvang die predikant ' $n$ traktement. Die traktement is nooit en onder geen omstandighede ' $n$ loon of 'n salaris nie, want die traktement is nooit betaling vir gelewerde diens nie. Die traktement is slegs daar om die predikant en sy huisgesin te versorg en te voorsien in sy lewensonderhoud sodat hy al sy tyd en aandag aan sy dienswerk kan wy. Hoewel die kerklike lewe in al te veel opsigte ' $n$ bespotting maak van die paar stellings wat hier genoem word, is dit in teorie so dat die grootte van die traktement nie belangrik geag word nie. Dit gaan slegs daarom dat die predikant'n stipendia iusta sal ontvang om so sy dienswerk te kan doen. Dit is inderdaad 'n saak van bekommernis dat so baie predikante die traktement en standplaas in ' $n$ gemeente sien en gebruik as ' $n$ platform om vandaar vir homself aardse, stoflike en wêreldse goedere en aansien te verwerf sonder om hom werklik te steur aan die gedage dat hy al sy tyd en aandag aan sy dienswerk moet wy. Juis die gedagte om "al sy tyd en aandag" te gaan omskrywe in so iets soos 'n agt uur werksdag of 'n veertig ure werksweek, is één van die dinge wat die aansien van die dienswerk verlaag en dit sekulariseer en ontledig van die roepingsinhoud en opdrag wat aan hierdie dienswerk verbonde is.

Om dus saam te vat, die begin én einde van die predikant se dienswerk is die prediking, die verkondiging, die uitleg en die toepassing van die Woord van God.

\section{Die Beëindiging van die Amp}

Wanneer oor die beẹindiging van die ampswerk gehandel word, moet in gedagte gehou word enersyds dat die Reformatoriese vadere die amp as 'n funksionele dienswerk gesien het èn andersyds dat die vadere geoordeel het dat die dienaar lewenslank tot die amp geroep is en lewenslank in die amp moet staan.

Formeel is daar 'n paar moontlikhede waarvolgens die dienswerk van die predikant beëindig kan word. Hulle is dan die volgende:

Dit kan deur die dood beëindig word.

Dit kan beëindig word deur emeritaat. Dit het vroeër in die Reformatoriese tyd beteken dat die predikant nadat hy ' $n$ leeftyd lank sy dienswerk volvoer het, nie meer die kragte het om sy dienswerk langer te volvoer nie. Dan word die predikant slegs 
losgemaak van sy verbintenis aan die gemeente maar behou hy die bevoegdheid om nog sy amp uit te oefen. In die Reformatoriese tyd was die voorwaarde vir die behoud van die emeritaat dat die uitgetrede predikant geen ander lewenstaak sal aanvaar nie. Solank as die predikant die geestelike en fisiese vermoë het om sy ampswerk te verrig, is hy deur sy roeping en sy opdrag van Godsweë verplig om in die volle diens van die evangelie te bly staan.

'n Ietwat lastige aangeleentheid is die vraag of die predikant op 'n bepaalde leeftyd verplig moet word om sy ampswerk te laat vaar. Dit is en bly ' $n$ lastige probleem juis omdat in die burgerlike lewe dit ' $n$ algemene saak is dat iemand op ongeveer 65-jarige leeftyd op pensioen sal gaan. Vanuit hierdie gedagte wat dit as aksiomaties sien dat 'n staats- of ander amptenaar op 65-jarige leeftyd met pensioen moet gaan, word nou gestel dat dit óók die predikant moet geld. In die burgerlike lewe word hierdie eis egter nié aan die professionele mense gestel nie. Nêrens word, na my wete, medici, juriste, argitekte en derglike professionele mense gedwing om op 65-jarige leeftyd hulle praktyk te laat vaar nie. Nou is dit wel interessant dat as vanuit die burgerlike lewe na die amp toe geredeneer word, die predikant as 'n amptenaar gesien word. Dit lyk my enigsins problematies, selfs in ons gesekulariseerde denke waarin die Skrif en die kerklike geskiedenis maar 'n geringe rol speel, om die predikant te gaan omskrywe as 'n kerklike amptenaar. Verpligte emeritaat op 65 -jarige leeftyd verlaag inderdaad 'n hoë roeping wat volgens die bevestigingsformulier van Godsweë kom en klassifiseer die predikant as 'n soort propagandis-organiseerder van 'n kerklike organisasie wat tot op sy 65-jarige leeftyd nog wel bruikbaar is maar daarna, ter wille van die goeie orde en die welsyn van die organisasie moet plek maak vir jonger, meer entoesiastiese kragte.

Dit is duidelik dat die amp wat ' $n$ dienswerk is wat ' $n$ mens van God self ontvang en wat volgens verskillende kerklike besluite al die tyd en aandag van die geroepe dienaar vereis, kwalik deur ' $n$ administratiewe reëling beëindig kan word. Baie Skriftuurlik is dit ook nie, want in die Ou Testament is daar, na my wete, nêrens sprake van 'n profeet wat op 65-jarige leeftyd verplig was om te swyg nie en in die Nuwe Testament geld dieselfde. As die Nuwe-Testamentiese wetenskap korrek is, het Johannes op Patmos in hoë ouderdom selfs nog 'n kanonieke geskrif opgestel sonder dat daar melding daarvan gemaak is dat hy nie meer as volwaardige apostel gegeld het nie.

As 'n predikant nie meer sy dienswerk na behore volvoer nie, is daar meer as voldoende kerklike moontlikhede om hom van sy 
amp los te maak. Maar dan is die toets nie 'n ouderdomstoets nie maar die vraag of sy dienswerk kwalitatief voldoen aan die eise wat gestel word. Dit bly vir my 'n vreemde gedagte dat 'n geroepe ampsdraer wat sy opdrag tot diens in die gemeente van die Heer van die kerk self ontvang, verplig moet word om sy verbintenis aan sy gemeente waarin hy so plegtig bevestig is, te laat vaar net omdat hy die 65 -jarige leeftyd bereik het.

'n Derde moontlikheid waarmee die dienswerk van dienaar van die Woord beëindig kan word, is deur ontheffing. Dit kan op twee gronde gebeur. Die een is as die dienaar van die Woord oorgaan na 'n ander lewenstaat, dit wil sê as die predikant sy dienswerk neerlê om 'n gewone burgerlike nering, ambag, beroep of betrekking te aanvaar. As 'n predikant so na 'n ander lewenstaat oorgaan, stel hy daarmee dat hy die dienswerk nie langer meer wil doen nie. Omdat die amp 'n funksionele amp is, is daar dan eintlik geen ander moontlikheid oor as om hom volledig van sy dienswerk te onthef nie. In die Reformatoriese tyd het die vadere in Skotland en Frankryk selfs 'n sterk sanksie verbind aan hierdie saak dat ' $n$ predikant na ' $n$ ander lewenstaat oorgaan. Juis omdat die amp as 'n roeping en 'n opdrag van God gesien is, is geoordeel dat oorgaan na 'n ander lewenstaat niks anders as ongehoorsaamheid aan die Heer van die kerk is nie. In ons tyd word die moontlikheid oopgelaat dat 'n dienaar van die Woord wat na ' $n$ ander lewenstaat oorgaan en dus die roeping nie meer wil volvoer nie, tog nog met die regte van die amp versier kan word.

'n Tweede moontlikheid van ontheffing is wanneer' $n$ dienaar van die Woord blyk gee dat hy ongeskik is of geword het om sy ampswerk langer te doen. Hierdie ontheffing geskied dan hoofsaaklik omdat die dienaar geestelik of fisies in so ' $n$ mate verswak of agteruitgegaan het dat daar nie ' $n$ ander moontlikheid bestaan as om hom te onthef nie. Dit wil my voorkom dat juis in hierdie kategorie óók daardie dienaars van die Woord kan val wat, as daar geen verpligte emeritaat is nie, tog volhard in die amp, al is dit duidelik dat hulle nie meer die vermoë het om die dienswerk te volvoer nie.

'n Vierde moontllikheid waarmee die dienswerk van 'n dienaar van die Woord beëindig kan word, is deur afsetting. Dit geskied wanneer ' $n$ predikant by die bevoegde vergaderings van die ampte aangekla, gehoor en skuldig bevind is aan die verkondiging van ' $n$ dwaalleer, of aan wangedrag, die versuim van ampspligte, die misbruik van ampsvoorregte en dergelike meer. Dit is natuurlik die donker skadukant van die roeping tot die amp en dit is dat die ampsdraer in sy opdrag faal.

In die geval van ameritaat-verlening, ontheffing en afsetting 
word dit, volgens ons kerklike orde, elke keer verleen deur dieselfde vergadering van die ampte as wat die kandidaat tot die amp toegelaat het.

As mens so na die begin en die einde van die dienswerk van die dienaar van die Woord kyk, die sentrale beginsels wat hier geld, so opnoem en ook merk wat ons as dienaars van die Woord daarvan maak, dan is dit seker belangrik dat ons voortdurend die belangrike uitspraak van die Eerste Switserse Geloofsbelydenis van 1536 sal onthou. Dáár het die vadere bely:

"Want Christus alléén is die ware en regmatige Hoof en Leraar van sy kerk. Dit is Hy self wat aan sy kerk herders en leraars gee wat, volgens sy bevel, die woord uitlê en die sleutelmag uitoefen in 'n geordende en reëlmatige manier." 